the disc and fields. For example, a case is quoted of cranio-pharyngeal pouch cyst, in which the sole symptoms complained of were mental deterioration and drowsiness. The discovery of early papilloedema led to X-ray examination which disclosed signs of calcified cyst. Operation followed and the boy completely recovered. The author remarks that had it not been for an ophthalmoscopic examination, it is highly probable that the boy would have passed eventually into an asylum, blind and mentally deranged.

Mention is also made of Walker's method of field examination, on a screen at two metres distance with test objects varying from 40 to $1 \mathrm{~mm}$. in diameter. It is noteworthy that the workers at the Clinic depend almost entirely on perimetry to distinguish between cerebellar tumours and those not infrequent temporal and occipital tumours which give cerebellar signs.

The method of quantitative perimetry is regarded by many as being a modern development of the old procedure, but it was actually described as long ago as 1896 by Simon, who, using a range of objects from $1.5 \mathrm{~mm}$. to $10 \mathrm{~mm}$. wrote " one must work out the size in each case."

Other methods of diagnosis which received consideration are, clinical investigation, $\mathrm{X}$-ray examination, ventriculography and exploratory craniotomy.

The description of these is followed by a section on treatment and the report closes with an instructive analysis of the fatal cases occurring during the year. The whole paper is excellently written and cannot fail to interest ophthalmologists, particularly those who are not satisfied merely with the diagnosis of optic atrophy but like to go further and find its cause.

\title{
OBITUARY
}

\section{Professor H. TRUC, of Montpellier}

THE recent death of Professor TRUC at the age of 72 has removed a well-known figure from the ranks of ophthalmology in France. Struggling successfully against unusual difficulties in early life Truc became a student of Medicine at Lyons, and obtained his doctorate in 1885 . He practised first as a general surgeon but two years later began to devote himself to ophthalmology. In 1891 he was appointed to the Chair of Ophthalmology at Montpellier University and held this post until he reached the age limit. Last year a commemorative medal was presented to him by his former pupils and colleagues.

Truc's contributions to ophthalmic literature were numerous 
and manysided. Among his important papers were those on Ocular Hygiene in relation to schools and workshops; he was also the author of a valuable and well-known book "Nouveaux Eléments d'Ophtalmologie." He was interested in the subject of heredity in disease of the eye and devoted much time and care to the investigation of congenital stationary night-blindness of which the remarkable Nougarien group occurred in his neighbourhood. He also showed much practical interest in the welfare of the blind.

\section{NOTES}

The Middlemore Prize of the British Medical Middlemore Prize Association (1928) has been awarded to Mr. W. S. Duke-Elder for an essay on "The Clinical Study of the Vitreous Body, its Swellings, Contractions, Opacities, and Reactions to Toxic Invasions : with special reference to Glaucoma and Detached Retina."

North of England Ophthalmological Society
THE officers of the North of England Ophthalmological Society for the Session 1929-1930 are as follows:-President, Thomas Snowball,

Burnley; Vice-President, H. Cecil Snell, Sheffield; Members of Council, J. D. McCulloch, Bradford, and W. M. Muirhead, Sheffield; Treasurer, W. H. Kiep, Bradford; Secretary, Percival J. Hay, Sheffield.

\section{FUTURE ARRANGEMENTS}

\section{9}

June 14.-Section of Ophthalmology, Royal Society of Medicine. (Annual Meeting).

July 4-5.-Oxford Ophthalmological Congress, at Oxford. September 5-13.-International Congress of Ophthalmology at Amsterdam.

\section{CONTEMPORARY OPHTHALMIC LITERATURE}

\section{American Journal of Ophthalmology. March.}

HOLBROOK LOWELL Measured correction of squint by combined technique. KEY. A case of trichinosis with exophthalmos.

O'RouRKE. The optical correction of conical cornea with the contact glass.

KNIGHTON. Hyperopic undercorrection due to retinoscopy.

Evans. A scotoma associated with strabismus. 